\title{
Banking on Silicon Docks
}

Last update: 25 November 2019

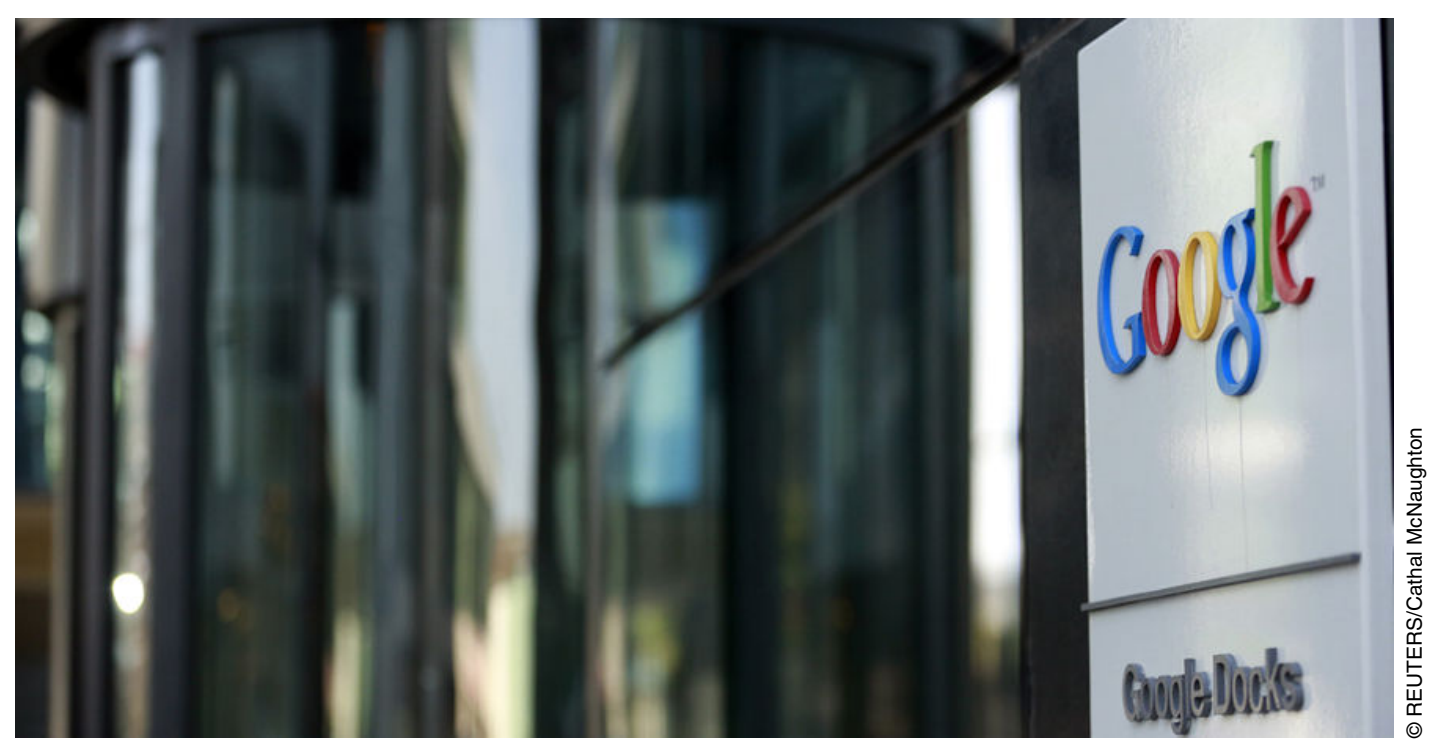

Even in today's "weightless" global economy, location has solid value. After all, it is no coincidence that Silicon Docks, the nickname of Dublin's high-tech hub, should emerge in Ireland. The culmination of a long-term vision to regenerate the capital's dilapidated port area and a dogged determination to convince a stillbudding if surging Google to set up its international headquarters in the capital in 2003, Silicon Docks, like Silicon Valley in California, is now attracting global attention. While technology companies such as Apple, Microsoft and Hewlett Packard all set up headquarters in Ireland beginning in the 1970s, it was Google's arrival in Dublin's docks that consolidated the country's attractiveness with a new contemporary edge.

It quickly became the pull factor for other investors, and today Silicon Docks, transformed by Dublin Docklands Authority is home to some 50 international tech firms, including the world's leading "born-on-the-internet" companies in sectors such as search, games, e-commerce, online payments, personal services and marketing.

The cluster effect of the big names Google, Facebook, Amazon, Yahoo, eBay and Twitter convinced US messaging service Slack to open its European office in Dublin in 2015, while Airbnb moved its European HQ to Dublin in 2014, creating 100 new jobs. Linkedin has also added its name to the list.

The Industrial Development Authority (IDA), the semi-state body charged with attracting foreign investment, estimates that the internet sector is worth over 40 
000 direct jobs, $€ 2$ billion in wages and $€ 1$ billion in corporate taxation, and predicts it will create an additional 45000 jobs by 2018.

The IDA showed vision setting up an emerging business unit in 2010 under its Horizon 2020 plan to attract new investors. In spite of the downturn, its marketing campaign to attract international tech firms into the area has succeeded in luring in companies such as Indeed.com, HubSpot, Dropbox and Facebook.

What seems certain is that low tax is not the only draw; true, at $12.5 \%$ Ireland's corporate tax rate is one of the lowest in Europe, though it is also true that many other jurisdictions offer low taxation, yet do not gain the same levels of inward investment. Ireland's highly skilled, well-educated and technologically savvy workforce has also been cited as a draw, while being an English-speaking country within the euro area is an obvious asset. Furthermore, the magnetic power of the Silicon Docks community is an attraction in its own right.

While Silicon Docks' original fraternity of behemoths has outgrown its original office space, with many of the global tech names expanding their presence there, it has morphed into a tech cluster,which spans central Dublin and gathers a cohort of Irish entrepreneurs, too.

It also helps to attract investment to the rest of Ireland. The tech world has been embedded outside the capital for decades, with giant tech companies, such as Apple in Cork and Hewlett-Packard (HP) in Galway. Indeed, Galway's own tech hub is now flourishing, with a solid talent pool flowing from local universities, and the presence of several major US tech companies including IBM, Cisco, HP and SmartBear Software. In 2015 HP's new innovation centre opened, marking its 44th year in Ireland. Apple also has heightening interest in Galway with its plans to create a monster data centre. Apple's European headquarters in Cork now employs more than 4000 people, making it the city's largest private-sector employer. Some of Cork's youngest technology companies, including Xanadu, Trustev and Teamwork, are thriving, and others are bubbling up in rural towns such as Skibbereen.

Efforts by these firms to reach out to the next generation show they are keen to stay. Some teach kids how to code and develop software; others are investing in partnerships with schools and universities.

Can Silicon Docks keep thriving, and investment in Cork and Galway and other places too? Much depends on global trends in technology, but also on constantly improving government policy towards innovation, skills and global trade. By spurring a stronger, more dynamic, sector, including among home-spun businesses, Ireland could become

By spurring a stronger, more dynamic, sector, including among homespun businesses, Ireland could become Europe's silicon coast Europe's silicon coast . Claire MacDonald 
See more on the Industrial Development Authority

\section{References}

Newenham, Pamela (2015), Silicon Docks: The Rise of Dublin as a Global Tech Hub, April,Liberties Press http://www.libertiespress.com/shop/silicon-docksthe-rise-of-dublin-as-a-global-tech-hub

Patnaude, Art (2015), “Tech Workers Flock to Dublin's Silicon Docks”, in The Wall Street Journal, May http://www.wsj.com/articles/tech-workers-flock-todublins-silicon-docks-1432822827 